Манюк Любов Володимирівна

старший викладач кафедри латинської та іноземних мов

Львівський медичний університет імені Данила Галицького, м. Львів, Україна

lyubov.manyuk@gmail.com

\title{
ВИКОРИСТАННЯ ЕЛЕКТРОННИХ СОЦАЛЬНИХ МЕРЕЖ У ПРОЦЕСІ ПІДГОТОВКИ МАЙБУТНІХ ЛІКАРІВ ДО ПРОФЕСІЙНОЇ ДІЯЛЬНОСТІ ТА ФАХОВОЇ КОМУНІКАЦЇ̈
}

\begin{abstract}
Анотація. У статті визначено педагогічні проблеми використання електронних соціальних мереж (ЕСМ) у навчальному процесі медичних вищих навчальних закладів (ВН3), проведено аналіз ролі та функцій викладача під час такого виду навчання, обгрунтовано переваги та недоліки використання ЕСМ під час навчання у медичних ВНЗ, описано досвід використання ЕСМ для підготовки майбутніх лікарів до професійної діяльності та фахової комунікації в Україні й за кордоном. Доведено, що впровадження навчання 3 використанням ЕСМ, що реалізує метод орієнтації на потреби студента, має велику кількість переваг, на відміну від консервативніших методів навчання, під час яких учасник навчального процесу не має таких простих можливостей доступу до інформації, глобальних навчальних мереж, міжнародної взаємодії та співпраці. Соціальні мережі мають позитивний вплив на розвиток майбутніх лікарів, готових до професійних викликів та самостійного навчання протягом життя.
\end{abstract}

Ключові слова: електронні соціальні мережі; майбутній лікар; фахова комунікація; професійна підготовка.

\section{1. ВСТУП}

Постановка проблеми. Розробникам електронних соціальних мереж (ЕСM), що стали трендом початку 21 століття, вдалося створити середовище, що практично усунуло географічні та фізичні комунікативні бар'єри, забезпечивши доступність спілкування із будь-ким у будь-якому куточку Землі у будь-який час. Серед педагогівметодистів усього світу ведуться дебати щодо використання таких технологій iз навчальною метою. Однак, незважаючи на суперечки науковців щодо позитивного та негативного впливу ЕСМ на розвиток та формування комунікативних навичок, процес використання численних ЕСМ в особистих, навчальних та професійних цілях невпинно зростає, кількість користувачів постійно збільшується, оператори мобільного зв'язку створюють спеціальні вигідні тарифи для користування популярними соціальними мережами, заохочуючи до ще активнішого їх застосування.

У зв'язку із зростанням кількості інформаційних технологій та їх користувачів, відбулася часткова трансформація та зміна орієнтації навчання, що у свою чергу відобразилося модифікацією потреб та вимог студентів. Набули популярності дистанційна, електронна та змішана форми навчання, сформувавши підгрунтя для виникнення нових педагогічних завдань [10]. Вищі навчальні заклади, в тому числі медичні, працюють над створенням методики інтеграції інформаційно-комунікаційних та соціальних технологій і мереж у навчальний процес, адже численні інструменти соціального програмного забезпечення сприяють кращій організації навчання студентів, надаючи можливість автономного користування, залучення до міжнародної спільноти, активного обміну та генерації знань.

Аналіз останніх досліджень і публікацій. Закордоном навчальний процес уже давно вийшов за межі традиційного уявлення про аудиторне навчання та все більше 
розвивається мережне навчання із залученням інформаційно-комунікаційних технологій (IКТ) $[1 ; 15 ; 18 ; 22]$. Сфера застосування IКТ та ЕСМ у вищій медичній освіті нашої країни, зокрема для розвитку навичок фахової комунікації не достатньо досліджена. Залишаються також відкритими питання застосування ЕСМ під час формального навчання студентів-медиків, створення моделей навчання iз використанням мережних технологій та методів використання таких технологій під час підготовки майбутніх лікарів, обгрунтування позитивного чи негативного впливу ЕСМ на процес навчання та визначення ролі викладача у процесі навчання та підготовки майбутніх лікарів до фахової комунікації із використанням соціальних мереж, що зумовлює актуальність даного дослідження.

Проблема використання ЕСМ у вищій медичній освіті досліджується вітчизняними $[1 ; 2 ; 5 ; 6 ; 7 ; 8 ; 9 ; 10 ; 11]$ та закордонними вченими $[13 ; 14 ; 15 ; 16$ $17 ; 18 ; 19 ; 20 ; 21 ; 22 ; 23 ; 24 ; 25]$. Зокрема, використання Інтернет-ресурсів для навчання студентів-медиків та необхідність створення власних Інтернет-джерел інформації для навчання майбутніх лікарів досліджують Д. Кук, К. Луглін та M. Лi (D. Cook, C. Loughlin, M. Lee), використання електронних соціальних мереж для навчання аналізували вітчизняні науковці -Р. Гуревич, С. Івашньова, О. Пінчук, Н. Стучинська, Т. Соколова та закордонні - К. Чест, Т. Флікінгер, М. Чізольм, Д. Джордж. К. Делласега, С. Бялий. А. Джалалі, Дж. Раян, Т. Кайнд, К. Шретіен (C. Chest, T. Flickinger, M. Chisolm, D. George, C. Dellasega, S. Bialy, A. Jalali, G. Ryan, T. Kind, K. Chretien), роль викладача у процесі навчання з використанням IКТ та ЕСМ описала P. Еллавей (R. Ellaway), використання ресурсів Інтернету для викладання та навчання практичного клініко-медичного матеріалу довели А. Райкос, П. Вайдеасекара, Т. Лі, К. Гао, К. Вонг, К. Тсе, Й. Чан (A. Raikos, P. Waidyasekara, T. Li, X. Gao, K. Wong, C. Tse, Y.Y. Chan).

Мета статті. Беручи до уваги сказане вище, мета цієї статті - визначити педагогічні проблеми використання IКТ та електронних соціальних мереж у навчальному процесі вищих медичних навчальних закладів (ВМН3), здійснити аналіз ролі та функцій викладача під час такого виду навчання, обгрунтувати переваги та недоліки використання ЕСМ під час навчання у медичних вишах, описати досвід використання ЕСМ для підготовки майбутніх лікарів до професійної діяльності та фахової комунікації в Україні та за кордоном.

\section{2. МЕТОДИ ДОСЛІДЖЕННЯ}

У дослідженні були використані теоретичні методи пошуку, аналізу, узагальнення та систематизації результатів вітчизняних та закордонних наукових досліджень, що стосуються проблеми застосування соціальних мереж під час підготовки майбутніх лікарів до професійної діяльності та фахової комунікації, а також було доповнено та грунтовніше обговорено результати власних попередніх досліджень з цієї тематики.

\section{3. РЕЗУЛЬТАТИ ДОСЛІДЖЕННЯ}

Використання ЕСМ як педагогічна проблема. Інтеграція компонентів електронного навчання у медичну освіту, використання IКТ та технологій соціального програмного забезпечення може вирішити низку педагогічних проблем цієї галузі, однією із яких $є$ персоналізація навчального середовища, тобто перехід від методу передачі знань до методу орієнтації процесу навчання відповідно до потреб студента. Таким чином, може бути створена нова модель навчання, у якій викладач виконуватиме 
роль координатора та наставника, сприятиме полегшенню процесу навчальної діяльності студентів [5; 8].

Студенти віку цифрових технологій надають перевагу технологічно-наповненому, активному, соціальному процесу навчання, зі збереженням права самостійного управління [14]. За умови належного методичного використання, соціальні мережі мають потенціал розвитку саморегульованого самостійного навчання, оскільки навчання за допомогою засобів ЕСМ $є$ активним, динамічним, основаним та керованим студентами. Саморегульоване навчання означає здатність суб'єкта навчального процесу самостійно моделювати своє навчання, організовувати, скеровувати та оцінювати свій процес навчання, осмислювати, критично та скептично ставитися до власних результатів, зберігаючи одночасно високий рівень мотивації. За допомогою таких процесів як моніторинг, рефлексія, тестування, анкетування та самооцінювання, учасник саморегульованого процесу навчання може виконувати навчальні дії, що ведуть до формування, досягнення знань та їх управління [19]. Такі навички, неодмінно, потрібні у сучасному динамічному світі, переповненому інформацією, коли рівень професіоналізму першочергово залежить від уміння вчитися i управляти процесом навчання.

На жаль, у нашій країні практика використання соціальних мереж у навчальних цілях студентами-медиками не дуже розповсюджена $[9 ; 11 ; 12]$. Загальновідомо, що електронні соціальні мережі використовуються більше із розважальною, комунікативною та загально-пізнавальною метою, ніж із навчальною. Хоча їх використання у викладацькій практиці могло б сприяти вирішенню багатьох педагогічних завдань, а саме: розвиток комунікативних навичок студента та здібностей роботи у команді; організація виконання домашніх завдань та самостійної роботи, завдяки цілодобовій доступності; розвиток персонального навчального середовища студента; індивідуальний підхід до кожного студента; усунення формальних бар'єрів між викладачем та студентом, що можуть перешкоджати ефективності навчання; зміна ролі та функцій викладача; створення електронного навчального змісту дисциплін; можливість міжнародної співпраці та обміну досвідом роботи між викладачами та студентами.

Серед вагомих аргументів на користь використання соціальних мереж у навчанні студентів необхідно також відзначати: звичні атмосфера та середовище спілкування, безкоштовність сервісу, можливість швидко та зручно обмінюватися важливою інформацією, мотивацію та зацікавленість до вивчення дисциплін, можливість взаємодії та участь у формуванні змісту навчання, незважаючи на такі фактори як хвороба, поїздка, тощо [6].

Використання ЕСМ для навчання сприяє орієнтації навчального процесу відповідно до потреб студентів. Останнім часом, концепт «персональне навчальне середовище» розглядається як застосування низки інструментів та можливостей Web 2.0, що служать для вирішення цієї педагогічної проблеми. Персоналізоване, орієнтоване на потреби студента навчальне середовище є перспективним засобом навчання, що може об'єднати новітні технології та педагогічні засади для вивчення нового за допомогою формування необхідних для такого роду навчання практичних навичок та стратегій мислення. Однак, педагогічні засади повинні бути орієнтовані не на процес викладання, а на процес самостійного навчання та контролю. Саме тому перед освітянами постало завдання створити необхідні структуровані методикопедагогічні засади для розвитку особистісно-орієнтованого, автономного навчання, щоб забезпечити накопичення необхідних знань і дати студентам варіанти вибору оптимального для них навчального методу [21; 23]. 
Окрім позитивного боку персоналізації навчального середовища, усунення ролі викладача як куратора змісту може мати негативні наслідки на процес навчання. Суперечливим видається твердження, що студенти здатні самостійно генерувати якісний навчальний контент, оцінювати корисність та правдивість інформації, зважаючи на обсяг та походження доступної інформації [14; 15]. У зв'язку із зміною потреб та компетенцій студентів, перед викладачами постало завдання залучення до навчального процесу ресурсів, що знаходяться за межами формального середовища навчального закладу, створення можливостей автентичного персоналізованого навчального середовища [16].

Однією із найбільших проблем методистів у створенні навчального матеріалу для такого виду ресурсів як соціальні мережі $є$ розуміння цілей навчання у певному контексті, тобто використання належної моделі, стратегії і тактики, для створення такого завдання, що відповідало б інтересам та зацікавленням студента [2]. У даному контексті викладач виконує допоміжну та діагностичну функції, відіграє роль спостерігача, консультанта, наглядача та куратора змісту [19]

У наш час, інформація доступна усім, усюди та у необмеженій кількості. Такий факт, беззаперечно, має як позитивні, так і негативні сторони, оскільки у відкритому доступі знаходиться і правдива, і недостовірна інформація, яку не завжди здатні відрізнити ті, що ще навчаються і не є фахівцями [1]. У контексті медичної освіти та практики дана ситуація може мати згубні наслідки. Саме тому пошук шляхів отримання коректної інформації, тобто відбір змісту, є одним із напрямків сучасних педагогічних досліджень. Опираючись на думку провідних науковців сфери використання інформаційно-комунікаційних технологій (IКТ) для навчання студентівмедиків, можна припустити, що варіантом вирішення такого завдання $є$ використання соціальних мереж із навчальною метою [14].

Рівень використання ЕСМ студентами та освітянами є досить високим [3; 4]. Дослідження в Україні та за кордоном підтвердили, що 100\% студентів мають відкриту сторінку у щонайменше одній соціальній мережі $[5 ; 13]$. Це ж стосується й студентівмедиків. Наприклад, аналіз інформації у мережі Facebook, що відбувався за пошуком "LNMU", показав, що Львівський національний медичний університет (ЛНМУ) імені Данила Галицького має офіційну сторінку в мережі Facebook (2244 учасники), на якій регулярно оновлюється корисна інформація навчального, адміністративного та виховного характеру, а також групи: Волонтерська група студентів-стоматологів (310 учасників), товариство молодих вчених і спеціалістів (85 учасників), новини ЛНМУ (287 учасників), студентське самоврядування (31 учасник), Наукова бібліотека, ЛНМУ, мед. факультет, 1994-2000 (152 учасники), студентське наукове товариство, кафедра хірургічної стоматології та щелепно-лицевої хірургії ЛНМУ (230 учасників). Із метою ознайомлення майбутніх лікарів із найновішими навчальними та необхідними загальноосвітніми матеріалами науково-педагогічними працівниками ЛНМУ імені Данила Галицького були створені такі навчальні групи у мережі Facebook: “Львівський фармацевтичний освітній портал" та "More English for Medical Students".

У згаданому вище навчальному закладі будо проведене дослідження у формі анкетування 3 метою виявлення стану використання засобів Інтернету для навчання. Одним із аспектів цього опитування студентів-медиків усіх років навчання було визначення стану залучення соціальних мереж у навчальний процес. На жаль, результат не виявився надто високим $(45 \%, 63 / 139)$ [7]. Проте цей вид подання відомостей до студентів є дуже перспективним, оскільки соціальні мережі можуть створювати зв'язок між студентами, які отримують навчальну інформацію за допомогою технологій та експерта галузі. Таким чином до студента потрапляють правдива та перевірена навчальна інформація. Окрім цього, згадані вище мережні технології сприяють 
модернізації та підвищенню якості навчання у ВМН3, сприяють розвитку навичок самостійного навчання, вирішення ситуативних задач і співпраці [5; 17].

Починаючи від 2010 року, команда науковців однієї із провідних компаній 3 розвитку освітніх технологій «Пірсон» (англ. Pearson) проводить дослідження використання ЕСМ під час викладання, що підтверджують зростання рівня використання СМ викладачами, як з особистою та професійною метою, так і для викладання [24]. За усі роки види ЕСМ залишаються незмінно стабільними, найпоширенішими із них визначено YouTube та Facebook. Відповідно до результатів опитування, у якому взяли участь 6000 респондентів-викладачів різних типів навчальних закладів у США, опублікованих у 2014 році, викладачі визначили стільки ж переваг у використанні ЕСМ, скільки й бар'єрів. Окрім цього, понад 3/4 викладачів зійшлися у думці, що ЕСМ підвищили рівень комунікативних умінь студентів, проте 4\% вважають, що погіршили та відволікають від справді необхідного контенту навчання.

Науковці кафедри інновацій університету Оттави у Канаді [13] дослідили точки зору викладачів і студентів-медиків щодо використання ЕСМ для навчання та виявили, що лише $33 \%$ опитаних викладачів використовували ЕСМ для співпраці зі студентами. Більшість викладачів не використовують ЕСМ для навчання, хоча i викладачі, i студенти вважають ці технології дружніми, такими, що економлять час, та зручними для навчання. Цікавим результатом дослідження було те, що викладачі використовують ECM, щоб поширювати статті, коментарі з поясненнями (англ. explanatory comments) та відео, а студенти, відповідно до результатів дослідження, надають перевагу електронним опитуванням (англ. quizzes), інформації для повторення (англ. revision files) та коментарям $з$ поясненнями [13]. Такий досвід закордонних колег може сприяти уникненню подібних помилок та стати прикладом у створенні власних новітніх засобів для навчання та формування компетентності у роботі з ресурсами Інтернету та ЕСМ, зокрема.

Використання можливостей ЕСМ для розвитку комунікативних навичок студентів-медиків. Як зазначалось вище, ЕСМ використовуються у практиці викладання для зручності комунікації між студентами, включаючи й тих, що знаходяться за межами аудиторії, та експертами певної галузі. Проте, оскільки такі технології є відкритими та доступними, вони потребують оцінки можливих ризиків та потреб тривалого спілкування у мережі.

У наш час сформовані комунікативні навички необхідні для успішного професійного розвитку, адже уміння грамотно та доречно спілкуватися характеризує рівень освіченості і є дуже необхідним для майбутніх лікарів. Достатньо новим явищем у практиці підготовки до фахової комунікації є використання таких інструментів ЕСМ, як віртуальні щоденники (англ. blog). За допомогою віртуальних щоденників, з'явилася можливість ведення бесіди, обміну знаннями та досвідом, а також взаємооцінювання. Проте, оскільки спілкування у ЕСМ проводиться здебільшого у письмовій формі, існує необхідність сформованих навичок письма, що $є$ непростим завданням навіть для носіїв мови, котрі мають труднощі із науковим письмом.

3 появою технологій Веб 2.0 з'явилася необхідність знання іноземних мов, а також нові гнучкіші можливості їх вивчення та викладання. Оскільки англійська мова $є$ мовою міжнародного спілкування - володіння нею $є$ неодмінними умовою та критерієм освіченості сучасного фахівця. За допомогою використання ЕСМ під час викладання англійської мови, можливо інтегрувати процес розвитку комунікативних навичок, англомовних комунікативних навичок та професійних англомовних комунікативних навичок. 3 метою полегшення та покращення процесу вивчення англійської мови науково-педагогічний колектив кафедри латинської та іноземних мов ЛНМУ імені 
Данила Галицького створили та керують групою "More English for medical students" у ECM Facebook.

Для студентів, які вивчають англійську мову, письмові завдання є особливим викликом, формування навичок вільного письма потребує великих зусиль та багато часу. Ведучи віртуальні щоденники, студенти окрім навичок вільного невимушеного письма також розвивають уміння мислити, приймати рішення, що написати та у якій кількості. Під час навчального процесу, що повністю керований викладачем (англ. instructor-oriented learning), існує низка перешкод для навчання вільного письма, адже студенти не мають можливості автономного навчання та прийняття рішень. Враховуючи перелічене вище, студентське аудиторне письмо $є$ радше грамотним, ніж вільним. На противагу, необтяжена, звична, дружня та невимушена для студентів атмосфера ЕСМ сприяє впевненішому використанню англійської мови на письмі та зменшенню рівня таких факторів як хвилювання, збудження та невпевненість [20].

Одне із досліджень, проведене Тайванськими вченими надає підтвердження позитивного впливу використання ECM, а саме мережі Facebook на розвиток навичок англомовного письма. Студенти, для навчання яких використовували можливості цієї мережі показали кращі результати із дисципліни на вихідному тесті порівняно із вхідним [25]. Викладач виконував допоміжну функцію та роль наглядача за процесом, проте брав участь у дискусіях та коментарях, коли вважав за доцільне. Суть процесу навчання полягала у розміщенні завдань викладачем на спеціально створених сторінках у мережі Facebook, завданням студентів було виконувати ці завдання та коментувати завдання одногрупників. Такий спосіб взаємного оцінювання студенти визнали дуже цікавим та ефективним, що було підтверджено жвавими дискусіями студентів. За результатами дослідження, використання можливостей Facebook $\epsilon$, беззаперечно, дуже корисним, проте потребує значних часових та фізичних зусиль, що пов'язані із керуванням, корегуванням та оцінюванням процесу викладачем.

\section{4. ВИСНОВКИ ТА ПЕРСПЕКТИВИ ПОДАЛЬШИХ ДОСЛІДЖЕНЬ}

На відміну від консервативніших методів навчання, впровадження навчання 3 використанням ЕСМ, що реалізує метод орієнтації на потреби студента, має велику кількість переваг, а саме: індивідуалізація й саморегулювання процесу навчання, розвиток комунікативних умінь, можливість доступу до інформації глобальних навчальних мереж, а також міжнародної взаємодії та співпраці. ЕСМ, безумовно, мають позитивний вплив на розвиток майбутніх лікарів, готових до професійних викликів та самостійного навчання протягом життя.

В результаті проведеного дослідження вдалося сформулювати основні проблеми використання ЕСМ у навчальному процесі ВМН3, до яких належать: вирішення педагогічних завдань пов'язаних із персоналізацією навчального середовища студентів, визначення ролі та функцій викладача під час навчання із залученням соціальних мережних технологій, забезпечення засобів та способів використання можливостей ECM у навчальному процесі із метою тренування професійних та комунікативних навичок майбутніх лікарів. Реальний досвід закордонних колег, котрі знаходяться попереду у даному напрямку дослідження, вказує на необхідність впровадження ЕСМ під час навчання у ВМНЗ з метою вирішення згаданих вище аспектів.

Отже, можна констатувати, що використання ЕСМ для навчання студентівмедиків є перспективним напрямком розвитку вищої медичної освіти. Однак, з метою кращого розуміння стану використання ЕСМ студентами-медиками, виявлення їх навчальних потреб, а також визначення шляхів практичного застосування ЕСМ 3 
урахуванням реалій підготовки майбутніх лікарів у вітчизняних медичних вишах потрібно провести додаткові дослідження.

\section{СПИСОК ВИКОРИСТАНИХ ДЖЕРЕЛ}

1. Гуревич Р. Інтернет і його соціальні мережі в сфері освіти: напрями використання [Електронний pecypc] / Р. Гуревич / Зб. наук. пр. III Міжнар. наук.-практ. конф. "Інформаційно-комунікаційні технології в сучасній освіті: досвід, проблеми, перспективи”. - С. 52-56. - Режим доступу: http://ubgd.lviv.ua/konferenc-/kon_ikt/plen_zasid/Gurevuch.pdf.

2. Івашньова С. В. Використання соціальних сервісів та соціальних мереж в освіті / С. В. Івашньова // Наукові записки НДУ ім. М. Гоголя. Психолого-педагогічні науки. - 2012. - № 2. - С. 15-17.

3. Клименко О. А. Социальные сети как средство обучения и взаимодействия участников образовательного процесса / О. А. Клименко // Теория и практика образования в современном мире: материалы Междунар. науч. конф. (г.Санкт-Петербург, фев. 2012 г.). - С.-Пб.: Реноме, 2012. - C. 405-407.

4. Крибель С. С. Использование социальных сетей в образовании / С. С. Крибель, В. В. Шобухова // Информатика и образование. - 2012. - № 4 (233). - С. 66-68.

5. Кучаковська Г.А. Застосування соціальних мереж в начальній діяльності студентів / Г.А. Кучаковська // Збірник матеріалів II Всеукраїнської науково-практичної конференції молодих учених «Наукова молодь-2014» . - К.: ІІТЗН НАПН України. - 2014. - С. 43-45.

6. Манюк Л.В. Статус соціальних мереж у вищій медичній освіті: все складно / Л.В. Манюк // Гуманітарна складова у світлі сучасних освітніх парадигм: [матеріали Всеукраїнської дистанційної науково-практичної конференції з міжнародною участю] (14-15 квітня 2016, Харків). - Х. : Вид-во НФаУб. - 2016. - С.199-202.

7. Манюк Л.В. Студент, Інтернет і медичний університет / Л.В. Манюк // Дистанційна освіта у ВНЗ: інноваційні та психолого-педагогічні аспекти / Збірка наукових праць Міжнародної науковометодичної конференції. - Харків : «Місьдрук», ХНАДУ. - 2015. С.152-156.

8. Пінчук О.П. Історико-аналітичний огляд розвитку соціальних мережних технологій і перспектив іх використання у навчанні [Електронний ресурс] / О.П. Пінчук // Інформаційні технології і засоби навчання. - 2015. - № 4 (48). - C. 14-34. - Режим доступу: http://journal.iitta.gov.ua/index.php/itlt/article/view/1267.

9. Радченко М.В. Освітній потенціал соціальних мереж як складової інформаційно-освітнього середовища [Електронний ресурс] / М.В. Радченко // Научный международный периодический журнал «Научные труды Sword». - 2014. - Режим доступу: http://www.sworld.com.ua/konfer35/726.pdf.

10. Стучинська Н.В. Дослідження комунікативної активності студентів медичного університету у соціальних мережах [Електронний ресурс] / Н.В. Стучинська, Т.О. Соколова // Інформаційні технології i засоби навчання. - 2011. - №3 (23). - Режим доступу: http://journal.iitta.gov.ua/index.php/itlt/article/view/425/408.

11. Тверезовська Н. Т. Роль і місце соціальних мереж у формуванні освітньо- інформаційного середовища аграрних університетів [Електронний ресурс] / Н. Т. Тверезовська, С. М. Мигович // Науковий вісник Національного університету біоресурсів і природокористування України. Серія : Педагогіка, психологія, філософія - - 2012. - Вип. 175(3). - С. 291-298. - Режим доступу: http://www.mnau.edu.ua/files/02_02_01_10/mygovich/2012-mygovich-rmsm.pdf.

12. Шуневич Б. Дистанційна освіта в Україні: навчальні матеріали / Б. Шуневич // Проблеми освіти: Науково-методичний збірник. - Київ: науково-методичний центр вищої освіти. - 2003. - № 31. C. 323-342.

13. Bialy S., Jalali A. (2015). Go Where the Students Are: A Comparison of the Use of Social Networking Sites Between Medical Students and Medical Educators [online]. JMIR: JMIR medical education. 1 (2). Retrieved from: http://mededu.jmir.org/2015/2/e7/.

14. Chest C.C., Flickinger T.E., Chisolm M.S. (2013). Social Media Use in Medical Education: A Systematic Review. Academic Medicine, June 2013,Volume 88, Issue 6, 893-901.

15. Cook D.A. (2006). Where are we with web-based learning in medical education? [online] Med teach., 28 (7). - P. 594-598. Retrieved from: http://www.ncbi.nlm.nih.gov/pubmed/17594549.

16. Ellaway R. (2011) eMedical Teacher. Med Teach, 33(12), 1038-1040. 
17. George D., Dellasega C. (2011). Social media in medical education: two innovative pilot studies [online]. Medical Education, Volume 45, Issue 11, 1158-1159. Retrieved from: http://onlinelibrary.wiley.com/doi/10.1111/j.1365-2923.2011.04124.x/full.

18. Li Tse Yan, Gao Xiaoli, Wong Kin, Tse Christine Shuk Kwan, Chan Ying Yee. (2015) Learning clinical procedures through Internet Digital Objects: Experience of undergraduate students Across Clinical Faculties [online]. JMIR mHealth and uHealth, Vol. 1 (1). Retrieved from http://mededu.jmir.org/2015/1/e1/.

19. Loughlin C., Lee M. (2010). Personalised and self regulated learning in the Web 2.0 era: International exemplars of innovative pedagogy using social software. [online] Australasian Journal of Educational Technology, 26(1), 28-43. Retrieved from: http://citeseerx.ist.psu.edu/viewdoc/download?doi=10.1.1.367.70\&rep=rep1\&type=pdf.

20. Purnima Iyer. (2013). Effects of Collaborative Blogging on Communicative Skills in Writing of Thai University EFL Students [online]. Journal of technology for ELT. Retrieved from: https://sites.google.com/site/journaloftechnologyforelt/archive/vol-3-no-3-july-oct-2013/5.

21. Raikos A. Waidyasekara P. (2014). How useful is YouTube in learning heart anatomy? Anat Sci Educ., 7(1), 12-18.

22. Ruiz J.G., Mintzer MJ, Leipzig RM. (2006) The impact of E-learning in medical education [online]. Acad Med, Vol 81(3), 207-212. Retrieved from http://www.ncbi.nlm.nih.gov/pubmed/16501260.

23. Ryan G., Kind T., Chretien K. (2010). Online Professionalism and the Mirror of Social Media. Journal of General Internal Medicine, Volume 25, Issue 11, 1227-1229.

24. Seaman J. , Tinti-Kane H. (2013) Social Media for Teaching and Learning [online]. Pearson Learning Solutions and Babson Survey Research Group. Retrieved from: http://www.meducationalliance.org/sites/default/files/social_media_for_teaching_and_learning.pdf.

25. Shih Ru-Chu. (2013). Effect of using Facebook to assist English for business communication course instruction [online]. Instruction TOJET: The Turkish Online Journal of Educational Technology, Volume 12, Issue 1, 52-59. Retrieved from: http://tojet.net/articles/v12i1/1216.pdf.

Матеріал надійшов до редакиіï 11.06.2016 p.

\title{
ИСПОЛЬЗОВАНИЕ ЭЛЕКТРОННЫХ СОЦИАЛЬНЫХ СЕТЕЙ В ПРОЦЕССЕ ПОДГОТОВКИ БУДУЩИХ ВРАЧЕЙ К ПРОФЕССИОНАЛЬНОЙ ДЕЯТЕЛЬНОСТИ И КОММУНИКАЦИИ
}

\author{
Манюк Любовь Владимировна \\ старший преподаватель кафедры латинского и иностранных языков \\ Львовский национальный медицинский университет имени Данила Галицкого, г. Львов, Украина \\ lyubov.manyuk@gmail.com
}

\begin{abstract}
Аннотация. В статье определены педагогические проблемы использования электронных социальных сетей (ЭСС) в учебном процессе высших медицинских учебных заведений, проведен анализ роли и функций преподавателя во время такого вида обучения, обоснованны преимущества и недостатки использования ЭСС во время учебы в медицинских вузах, описан опыт использования ЭСС для подготовки будущих врачей к профессиональной деятельности и коммуникации в Украине и за рубежом. Доказано, что внедрение обучения с использованием ЭСС, реализующего метод ориентации на потребности студента, имеет большое количество преимуществ, в отличие от консервативных методов обучения, при которых участник учебного процесса не имеет таких простых возможностей доступа к информации, глобальных учебных сетей, международного взаимодействия и сотрудничества. Электронные социальные сети оказывают положительное влияние на развитие будущих врачей, готовых к профессиональным вызовам и самостоятельному обучению в течение жизни.
\end{abstract}

Ключевые слова: электронные социальные сети; будущий врач; профессиональная коммуникация; профессиональная подготовка. 


\title{
SOCIAL MEDIA IN THE PROCESS OF PROFESSIONAL AND COMMUNICATIVE SKILLS TRAINING OF FUTURE PHYSICIANS
}

\author{
Liubov V. Maniuk \\ Seniour lecturer at the Department of Latin and Foreign Languages \\ Danylo Halytsky Lviv National Medical University, Lviv, Ukraine \\ lyubov.manyuk@gmail.com
}

\begin{abstract}
The article states the pedagogical problems of social media usage in studying at higher medical educational institutions, analyses the role and functions of a tutor in the learning process, grounds the advantages and disadvantages of social media implementation in higher medical education, describes the experience of social networks usage in professional and communicative skills training of future physicians in Ukraine and abroad. It has been proved that implementation of social media aids to realize the student-oriented methodological approach. Furthermore, it benefits from the conservative learning methods in which the student does not have the same possibilities of open access to information, global networking sites, international cooperation and collaboration. Social media have the positive influence on the development of future physicians, ready to the professional challenges, continuous individual learning and self-study.
\end{abstract}

Keywords: social media; future physician; professional communication; professional training.

\section{REFERENCES (TRANSLATED AND TRANSLITERATED)}

1. Hurevych R. Internet and its social media in the educational sphere: directions of the use [online] / R. Hurevych / Book of scientific papers of the III International scientific and practical conference "Information and communication technologies in current education: experience, problems, perspectives". - P. 52-56. - Available from: http://ubgd.lviv.ua/konferenc-/kon_ikt/plen_zasid/Gurevuch.pdf. (in Ukrainian).

2. Ivashniova C.V. The usage of social services and social networks in education / S.V. Ivashniova // Scientific notes of M. Hohol NSU. Psychological and pedagogical sciences. - 2012. - No 2. - P. 15-17. (in Ukrainian).

3. Klymenko O.A. Social networks as the instrument of education and interaction of students / O. A. Klymenko // Educational Theory and Practice in the Modern World: the proceedings of the International scientific conference (St. Petersburg, Feb 2012) . - S.-Pb.: Renome, 2012. - P. 405-407. (in Russian).

4. Krybel S.S. The implementation of social media in education / S.S. Krybel, V/V/ Shobuhova // Informatiocs and education. - 2012. - No 4 (233). - P. 66-68. (in Russian).

5. Kulachkovska N.A. Using social media in students' learning activity / Kulachkovska N.A. // Proceedings of the 2nd Ukrainian scientific conference of young scientists "Scientific youth - 2014", Kyiv, IITZNH APSU. - 2014. - P. 43-45. (in Ukrainian).

6. Manyuk L.V. The status of social media in higher medical education: it is complicated. / Manyuk L.V. // Humanitarian component in the light of current educational paradigms: [Proceedings of Whole-Ukrainian distance scientific and practical conference with foreign participation] (14th-15th April 2015, Kharkiv). Kharkiv: Printing House Of National Pharmaceutical Academy. - P. 199-202. (in Ukrainian).

7. Manyuk L.V. Student, Internet and Medical University. / Manyuk L.V. // Distance education in higher educational institutions: innovation and psychologically pedagogical aspects / Book of scientific papers of International scientific methodical conference. - Kharkiv : City Print, 2015. - P. 152-156. (in Ukrainian).

8. Pinchuk O.P. Historical and analytical review of social networking technologies and pospects of their use in training [online] / Pinchuk O.P. // Information Technologies and Learning Tools, [S.1.], V. 48, No. 4, P. 14-34. - Available from: <http://journal.iitta.gov.ua/index.php/itlt/article/view/1267>. (in Ukrainian).

9. Radchenko M.V. Educational potential of social media as the component of informative-educational medium [online] / Radchenko M.V.// Scientific international periodical journal "Scientific papers Sword". -, 17-28 June 2014. - Available from: http://www.sworld.com.ua/konfer35/726.pdf. (in Ukrainian).

10. Stuchynska N.V. Research of medical universities' students communicative activity in social networks [online] / Stuchynska N.V., Sokolova T. A. // Information Technologies and Learning Tools, [S.1.]. - Vol. 23. - n. 3. - 2011. - Available from: http://journal.iitta.gov.ua/index.php/itlt/article/view/425. (in Ukrainian) 
11. Tverezovska N.T. The role and the place of social networks in the formation of educational informative medium at agricultural universities [online] / N.T. Tverezovska, S.M. Myhovych // Scientific journal of National university of biological resources and natural usage of Ukraine. Series: Pedagogics, psychology, philosophy. - 2012. - Vol. 175(3). - P. 291-298. - Available from: http://www.mnau.edu.ua/files/02_02_01_10/mygovich/2012-mygovich-rmsm.pdf. (in Ukrainian).

12. Shunevych B. Distance education in Ukraine: learning materials / B. Shunevych // Educational problems: Scientific methodical book of articles. - Kyiv: Scientific methodical centre of higher education, 2003. No 31. - P. 323-342. (in Ukrainian).

13. Bialy S., Jalali A. (2015). Go Where the Students Are: A Comparison of the Use of Social Networking Sites Between Medical Students and Medical Educators [online]. JMIR: JMIR medical education. 1 (2). Available from: http://mededu.jmir.org/2015/2/e7/. (in English)

14. Chest C.C., Flickinger T.E., Chisolm M.S. (2013). Social Media Use in Medical Education: A Systematic Review. Academic Medicine, June 2013,Volume 88, Issue 6, 893-901. (in English)

15. Cook D.A. (2006). Where are we with web-based learning in medical education? [online] Med teach., 28 (7). - P. 594-598. Available from: http://www.ncbi.nlm.nih.gov/pubmed/17594549. (in English)

16. Ellaway R. (2011) eMedical Teacher. Med Teach, 33(12), 1038-1040. (in English)

17. George D., Dellasega C. (2011). Social media in medical education: two innovative pilot studies [online]. Medical Education, Volume 45, Issue 11, 1158-1159. Available from: http://onlinelibrary.wiley.com/doi/10.1111/j.1365-2923.2011.04124.x/full. (in English)

18. Li Tse Yan, Gao Xiaoli, Wong Kin, Tse Christine Shuk Kwan, Chan Ying Yee. (2015) Learning clinical procedures through Internet Digital Objects: Experience of undergraduate students Across Clinical Faculties. [online] JMIR mHealth and uHealth, Vol. 1 (1). Available from http://mededu.jmir.org/2015/1/e1/. (in English)

19. Loughlin C., Lee M. (2010). Personalised and self regulated learning in the Web 2.0 era: International exemplars of innovative pedagogy using social software. [online] Australasian Journal of Educational Technology, 26(1), 28-43. Available from: http://citeseerx.ist.psu.edu/viewdoc/download?doi=10.1.1.367.70\&rep=rep1\&type=pdf. (in English)

20. Purnima Iyer. (2013). Effects of Collaborative Blogging on Communicative Skills in Writing of Thai University EFL Students. [online] Journal of technology for ELT. Available from: https://sites.google.com/site/journaloftechnologyforelt/archive/vol-3-no-3-july-oct-2013/5. (in English)

21. Raikos A. Waidyasekara P. (2014). How useful is YouTube in learning heart anatomy? Anat Sci Educ., 7(1), 12-18. (in English)

22. Ruiz J.G., Mintzer MJ, Leipzig RM. (2006) The impact of E-learning in medical education. [online] Acad Med, Vol 81(3), 207-212. Available from http://www.ncbi.nlm.nih.gov/pubmed/16501260. (in English)

23. Ryan G., Kind T., Chretien K. (2010). Online Professionalism and the Mirror of Social Media. Journal of General Internal Medicine, Volume 25, Issue 11, 1227-1229. (in English)

24. Seaman J. , Tinti-Kane H. (2013)Social Media for Teaching and Learning. [online] Pearson Learning Solutions and Babson Survey Research Group. Available from: http://www.meducationalliance.org/sites/default/files/social_media_for_teaching_and_learning.pdf. (in English)

25. Shih Ru-Chu. (2013). Effect of using Facebook to assist English for business communication course instruction. [online] Instruction TOJET: The Turkish Online Journal of Educational Technology, Volume 12, Issue 1, 52-59. Available from: http://tojet.net/articles/v12i1/1216.pdf. (in English)

Conflict of interest. The author has declared no conflict of interest.

\section{(cc) BY-NC-SA}

This work is licensed under Creative Commons Attribution-NonCommercial-ShareAlike 4.0 International License. 